\title{
Bending Creep Property of Cross-Laminated Woods Made With Six Domestic Species ${ }^{1}$
}

\author{
Jin-Woong Byeon ${ }^{2} \cdot$ Tae-Ho Kim² ${ }^{2}$ Jae-Kyung Yang ${ }^{2} \cdot$ Hee-Seop Byeon ${ }^{2} \cdot$ Han-Min Park $\mathbb{D}^{2, \dagger}$
}

\begin{abstract}
In this study, with the view to using effectively small and medium diameter Korean domestic woods as structural materials, cross-laminated woods were manufactured by using six species of Korean domestic softwoods and hardwoods, and bending creep properties were investigated for each species. The creep curves showed the shape of the exponential function plot, and the creep curves after 1 hour were able to estimate by fitting it to the power law. The initial and creep compliances of cross-laminated woods showed the higher values in wood species with a low density than in that with a high density. And by cross-laminating, the initial and creep compliances perpendicular to the grain considerably decreased, the extent of the decrease was found to be greater in creep deformation than in initial deformation. The creep anisotropies of cross-laminated woods were considerably decreased by cross-laminating. The relative creep of $\mathrm{C}_{\perp}$ type composed of perpendicular-direction lamina in the faces decreased $0.59-0.64$ times compared to that of $\mathrm{P}_{\perp}$ type composed of perpendicular-direction laminae in all layers, and that for $\mathrm{C}_{\|}$type composed of parallel-direction laminae in the faces increased $1.5-1.6$ times compared to that of $\mathrm{P}_{\|}$type composed of parallel-direction laminae in all layers.
\end{abstract}

Keywords : species, cross-laminated woods, anisotropy, initial deformation, creep deformation, relative creep

\section{INTRODUCTION}

Approximately $63 \%$ of South Korea is under forest cover, the growing stock accumulation exceed the average of OECD countries (Korea Forest Service, 2016). Thus the necessity of wood use is increased, and extending the use and technical development of wood are required.
The creep behaviors of wood and wood-based materials have been studied for solid woods (Schniewind, 1968; Aratake et al., 2002), glulam (Fushitani and Bono, 1975; Hoyle et al., 1994), and various wood-based boards (Okuma and Tashiro, 1968; Bryan and Schniewind, 1965; Saito et al., 1980; Moslemi, 1964). In recent years, there is a growing interest in CLT which can be widely used in flooring, walls

1 Date Received July 11, 2017, Date Accepted August 20, 2017

2 Division of Environmental Forest Science, Institute of Agriculture \& Life Science, Gyeongsang National University, Jinju 52828, Republic of Korea.

${ }^{\dagger}$ Corresponding author: Han-Min Park (e-mail: phm0691@gnu.ac.kr, ORCID: 0000-0001-6322-5985) 
and ceilings owing to significantly reducing the anisotropy of woods by cross-laminating. Therefore, various researches for mechanical properties have been conducted such as the bending properties (Gülzow et al., 2011; Stelger et al., 2012; Goto et al., 2014), the shear properties (Okabe et al., 2014; Nakashima et al., 2014), the compressive properties (Ido et al., 2014) and the torsion properties (Sebera et al., 2015) and for the connection such as typical metal and screwed connectors (Gavric et al., 2014; 2015). However, the researches on creep behaviors of CLT recognize its importance, but the accumulation of the research is very small, and the research is expected to be activated. In the previous report (Park et al., 2016), with a view to effectively use small- and medium-diameter Korean wood as structural materials, cross-laminated woods were manufactured using six species of Korean softwoods and hardwoods, and static bending strength performances were investigated. As a results, the bending strength performances increased with the densities of wood species, and the anisotropy was markedly reduced by cross-laminating, and the bending strength performances perpendicular to the grain markedly improved. Also, the ratios of the measured values to the estimated values were almost similar in the cross-laminated woods with perpendicular-direction laminae in the faces, but it was very great in the cross-laminated woods with parallel-direction laminae in the faces. This was considered due to the effects of deflection caused by shear forces as the results of various cross-laminated woods manufactured with several wood species studied for many years by the authors (Park et al., 2001, 2002, 2003, 2006, 2009; Park and Fushitani, 2006, 2014). It was found that the extent of the influence was greater in softwoods with a low shear modulus than in hardwoods.

In this study, in addition to the previous study, 24 types of parallel- and cross-laminated woods were manufactured using six Korean domestic woods, and bending creep test was performed, and the influence of wood species on creep property was investigated.

\section{MATERIALS and METHODS}

\subsection{Specimen preparation}

Six species of Korean domestic woods were selected for this study. They included three softwoods: Japanese cedar, Japanese cypress and Japanese larch; three hardwoods: chestnut, tulip tree and oriental oak. Longitudinal-direction laminae of $6.7(\mathrm{~T}) \times 20(\mathrm{R}) \times 360(\mathrm{~L}) \mathrm{mm}$ whose long axes were parallel to the grain were made with six species. And perpendicular-direction laminae were made as follows. First, longitudinal elements of $7.5(\mathrm{~T}) \times 20(\mathrm{R}) \times 180(\mathrm{~L})$ $\mathrm{mm}$ parallel to the grain were made from six species and the 18 elements of them were side-jointed in the square frame. And $30 \mathrm{rec}-$ tangular plates of $7.5(\mathrm{~T}) \times 360(\mathrm{R}) \times 180(\mathrm{~L})$ $\mathrm{mm}$ were manufactured from each species, and then the plates were cut to $20 \mathrm{~mm}$ size in width direction and perpendicular-direction laminae of $6.7(\mathrm{~T}) \times 360(\mathrm{R}) \times 20(\mathrm{~L}) \mathrm{mm}$ were made with long axes perpendicular to the grain. 


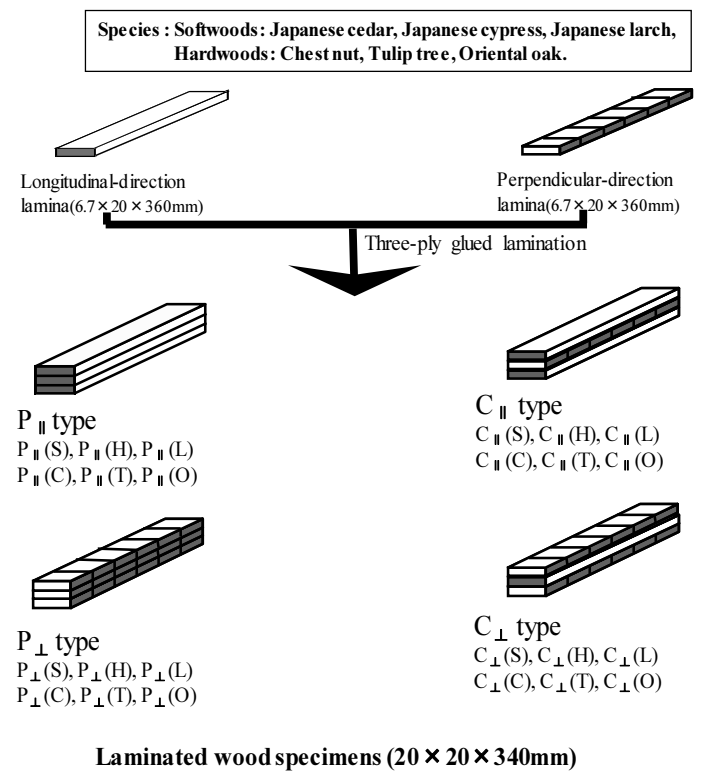

Fig. 1. Parallel- and cross-laminated woods made with six species. S, H, L, C, T and $\mathrm{O}$ are Japanese cedar, Japanese cypress, Japanese larch, chestnut, tulip tree and oriental oak, respectively.

The annual ring angles of both laminae were $90^{\circ}$. An isocyanate type adhesive (MPU-500, Okong Co. Ltd.) formulated for a room temperature cure was used, and the amount of spread was $300 \mathrm{~g} / \mathrm{m}^{2}$. The three-ply laminae were pressed under pressure of $0.34 \mathrm{MPa}$ for 24 hours at $20^{\circ} \mathrm{C}$ and $65 \%$ RH. Fig. 1 shows three-ply parallel- and cross-laminated wood specimens tested. $\mathrm{P}_{\|}$type $\left(\mathrm{P}_{\|}(\mathrm{S}), \mathrm{P}_{\|}(\mathrm{H}), \mathrm{P}_{\|}\right.$ $(\mathrm{L}), \quad \mathrm{P}_{\|}(\mathrm{C}), \quad \mathrm{P}_{\|}(\mathrm{T})$ and $\mathrm{P}_{\|}(\mathrm{O})$, where $\mathrm{S}$ : Japanese cedar, H: Japanese cypress, L: Japanese larch, C: Chestnut, T: Tulip tree, O: Oriental oak) and $\mathrm{P}_{\perp}$ type $\left(\mathrm{P}_{\perp}(\mathrm{S}), \mathrm{P}_{\perp}(\mathrm{H}), \mathrm{P}_{\perp}\right.$ (L), $\mathrm{P}_{\perp}(\mathrm{C}), \mathrm{P}_{\perp}(\mathrm{T})$ and $\mathrm{P}_{\perp}(\mathrm{O})$ ) were the specimens used to measure the bending creep parallel and perpendicular to the grain of parallel-laminated woods, respectively. And $\mathrm{C}_{\|}$type
$\left(\mathrm{C}_{\|}(\mathrm{S}), \mathrm{C}_{\|}(\mathrm{H}), \mathrm{C}_{\|}(\mathrm{L}), \mathrm{C}_{\|}(\mathrm{C}), \mathrm{C}_{\|}(\mathrm{T})\right.$ and $\mathrm{C}_{\|}$ (O)) and $\mathrm{C}_{\perp}$ type $\left(\mathrm{C}_{\perp}(\mathrm{S}), \mathrm{C}_{\perp}(\mathrm{H}), \mathrm{C}_{\perp}(\mathrm{L}), \mathrm{C}_{\perp}\right.$ (C), $\mathrm{C}_{\perp}(\mathrm{T})$ and $\mathrm{C}_{\perp}(\mathrm{O})$ ) were the specimens used to measure the bending creep parallel and perpendicular to the grain of the face laminae of cross-laminated woods, respectively. There were 3 of each type of specimen, for a total of 72 specimens.

\subsection{Bending creep test}

Bending creep test for parallel- and cross-laminated wood specimens was conducted by four-point loading as shown in Fig. 2. The span was $300 \mathrm{~mm}$, and the distance between a loading point and a supporting point was 100 $\mathrm{mm}$. The stress corresponding to $25 \%$ of breaking stress obtained from static bending test was applied to each specimen. The applied stresses were the average values of four bending test specimens, and the applied stresses and its coefficient of variations (CV) are shown in Table 1. The creep test was conducted for $168 \mathrm{~h}$ (7 days) in a constant atmosphere maintained at $20^{\circ} \mathrm{C}$ and $65 \%$ RH. The deflection of the mid-span was measured with a dial gauge. Total creep compliance $D(t)$ and creep compliance $D_{\mathrm{c}}(t)$ (total creep compliance except for initial compliance) were obtained using Eqs. (1) and (2) as follows:

$$
D(t)=4 b h^{3} y(t) / P a\left(3 l^{2}-4 a^{2}\right)
$$

where $P$ is the applied load; $l$ is the span; $b, h$ are the width and depth of the beam; $a$ is the 
Jin-Woong Byeon $\cdot$ Tae-Ho Kim $\cdot$ Jae-Kyung Yang $\cdot$ Hee-Seop Byeon $\cdot$ Han-Min Park

Table 1. Applied stresses of bending creep for the parallel-and cross-laminated woods

\begin{tabular}{cccccccc}
\hline Type & $\begin{array}{c}\text { Applied stress } \\
(\mathrm{MPa})\end{array}$ & Type & $\begin{array}{c}\text { Applied stress } \\
(\mathrm{MPa})\end{array}$ & Type & $\begin{array}{c}\text { Applied stress } \\
(\mathrm{MPa})\end{array}$ & $\begin{array}{c}\text { Type } \\
\begin{array}{c}\text { Applied stress } \\
(\mathrm{MPa})\end{array}\end{array}$ \\
\hline \hline $\mathrm{P}_{\|}(\mathrm{S})$ & $14.2(5.6)$ & $\mathrm{P}_{\perp}(\mathrm{S})$ & $1.2(14.2)$ & $\mathrm{C}_{\|}(\mathrm{S})$ & $11.9(9.4)$ & $\mathrm{C}_{\perp}(\mathrm{S})$ & $2.5(3.5)$ \\
$\mathrm{P}_{\|}(\mathrm{H})$ & $17.7(5.1)$ & $\mathrm{P}_{\perp}(\mathrm{H})$ & $2.5(12.2)$ & $\mathrm{C}_{\|}(\mathrm{H})$ & $14.4(5.2)$ & $\mathrm{C}_{\perp}(\mathrm{H})$ & $3.4(4.8)$ \\
$\mathrm{P}_{\|}(\mathrm{L})$ & $23.6(9.0)$ & $\mathrm{P}_{\perp}(\mathrm{L})$ & $1.9(8.4)$ & $\mathrm{C}_{\|}(\mathrm{L})$ & $18.3(4.2)$ & $\mathrm{C}_{\perp}(\mathrm{L})$ & $3.9(8.7)$ \\
$\mathrm{P}_{\|}(\mathrm{C})$ & $19.5(9.8)$ & $\mathrm{P}_{\perp}(\mathrm{C})$ & $2.5(10.0)$ & $\mathrm{C}_{\|}(\mathrm{C})$ & $16.6(4.6)$ & $\mathrm{C}_{\perp}(\mathrm{C})$ & $3.5(9.5)$ \\
$\mathrm{P}_{\|}(\mathrm{T})$ & $19.8(9.6)$ & $\mathrm{P}_{\perp}(\mathrm{T})$ & $3.9(9.5)$ & $\mathrm{C}_{\|}(\mathrm{T})$ & $17.0(16.1)$ & $\mathrm{C}_{\perp}(\mathrm{T})$ & $5.3(7.9)$ \\
$\mathrm{P}_{\|}(\mathrm{O})$ & $28.5(10.0)$ & $\mathrm{P}_{\perp}(\mathrm{O})$ & $4.5(17.6)$ & $\mathrm{C}_{\|}(\mathrm{O})$ & $24.7(4.8)$ & $\mathrm{C}_{\perp}(\mathrm{O})$ & $5.9(6.2)$ \\
\hline
\end{tabular}

Each value in parentheses is the coefficient of variation (\%).

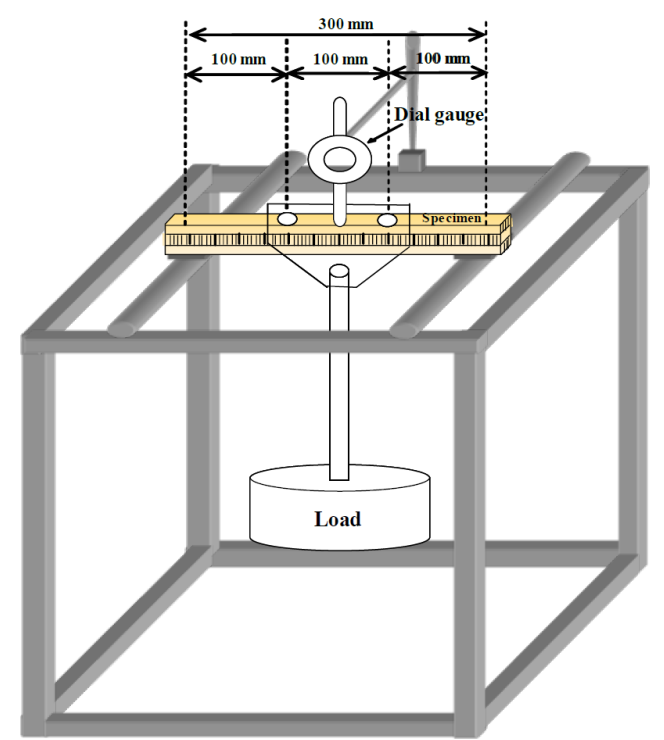

Fig. 2. Schematic diagram of bending creep test.

distance between a loading point and a supporting point; and $y(t)$ is the apparent deflection at time $(t)$ between both supporting points and contains the deflection caused by shear force. Therefore, $D(t)$ is the apparent total creep compliance obtained from the apparent deflection containing the deflection caused by shear force.

$$
D_{\mathrm{c}}(t)=D(t)-D(0.008)
$$

where $D(0.008)$ is the creep compliance at $t=$ $0.008 \mathrm{~h}(30 \mathrm{~s})$ and called initial compliance.

\section{REULTS and DISCUSSION}

\subsection{Bending creep curves of laminated woods}

Fig. 3 shows typical examples of creep curves of parallel- and cross-laminated woods made with domestic six species. The creep curves showed the shape of the exponential function plot which markedly increased at upper right side with the increase of time, and the extent of the increase was higher in the laminated woods made with Japanese cedar with the lowest density than in that made with oriental oak with the highest density of the tested species. It was found to be higher in softwoods than in hardwoods.

Fig. 4 shows the double logarithm plots of creep compliances and time for each type of laminated wood specimens. The creep curves showed a curvilinear behavior for about $30 \mathrm{mi}$ nute to 1 hour after loading, but then showed a linear behavior. It has been reported in many 

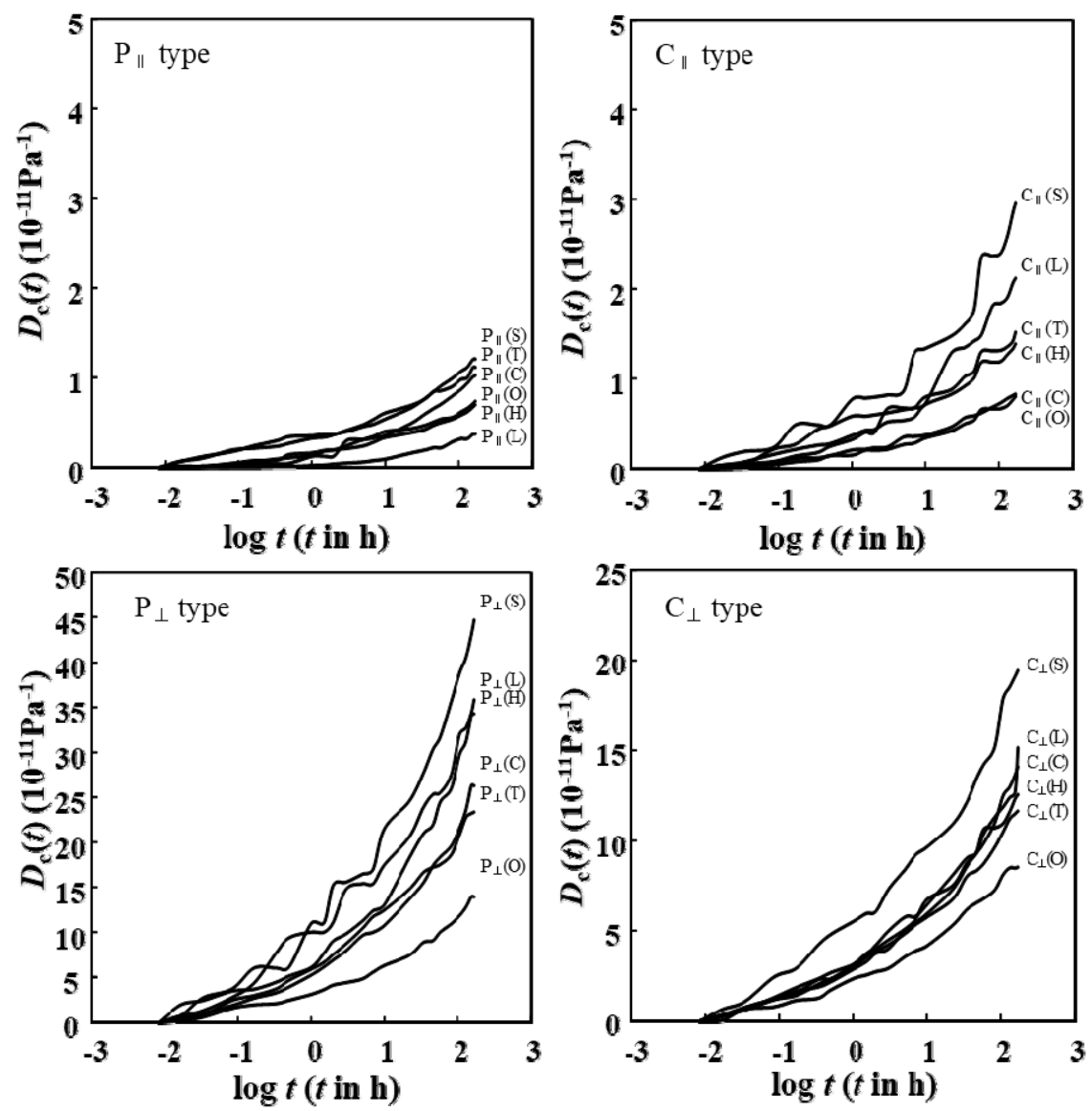

Fig. 3. Typical examples of creep curves for $\mathrm{P}_{\|}, \mathrm{P}_{\perp}, \mathrm{C}_{\|}$and $\mathrm{C}_{\perp}$ type laminated woods. $\mathrm{S}, \mathrm{H}, \mathrm{L}, \mathrm{C}, \mathrm{T}$ and $\mathrm{O}$ are Japanese cedar, Japanese cypress, Japanese larch, chestnut, tulip tree and oriental oak, respectively.

papers that the creep curves of wood and wood-based materials were fitted to power law expressed by Eq. (3) (Schniewind, 1968; Saito et al., 1980; Arima et al., 1981; Morizumi, 1981; Hoyle et al., 1994; Aratake et al., 2002).

$$
D_{\mathrm{c}}(t)=A t^{N}
$$

where, $A$ and $N$ are constants, and $t$ is time.

In the logarithm regression of Eq. (3), the correlation coefficients were in the range of
$0.978-0.998$. The fitted values of $N$ and $A$ are shown in Table 2.

The $N$ values of $\mathrm{P}_{\|}$type that were composed of parallel-direction laminae in all layers were in the range of $0.261-0.437$, and $\mathrm{P}_{\|}(\mathrm{H})$ composed of Japanese cypress had the lowest value, and had the highest value in $\mathrm{P}_{\|}(\mathrm{L})$ composed of Japanese larch with a high coefficient of variation among the specimens. The values were in order of $\mathrm{P}_{\|}(\mathrm{L})>\mathrm{P}_{\|}(\mathrm{C})>\mathrm{P}_{\|}(\mathrm{S})>$ $\mathrm{P}_{\|}(\mathrm{O})>\mathrm{P}_{\|}(\mathrm{T})>\mathrm{P}_{\|}(\mathrm{H})$. It was found that there 
Jin-Woong Byeon $\cdot$ Tae-Ho Kim $\cdot$ Jae-Kyung Yang $\cdot$ Hee-Seop Byeon $\cdot$ Han-Min Park

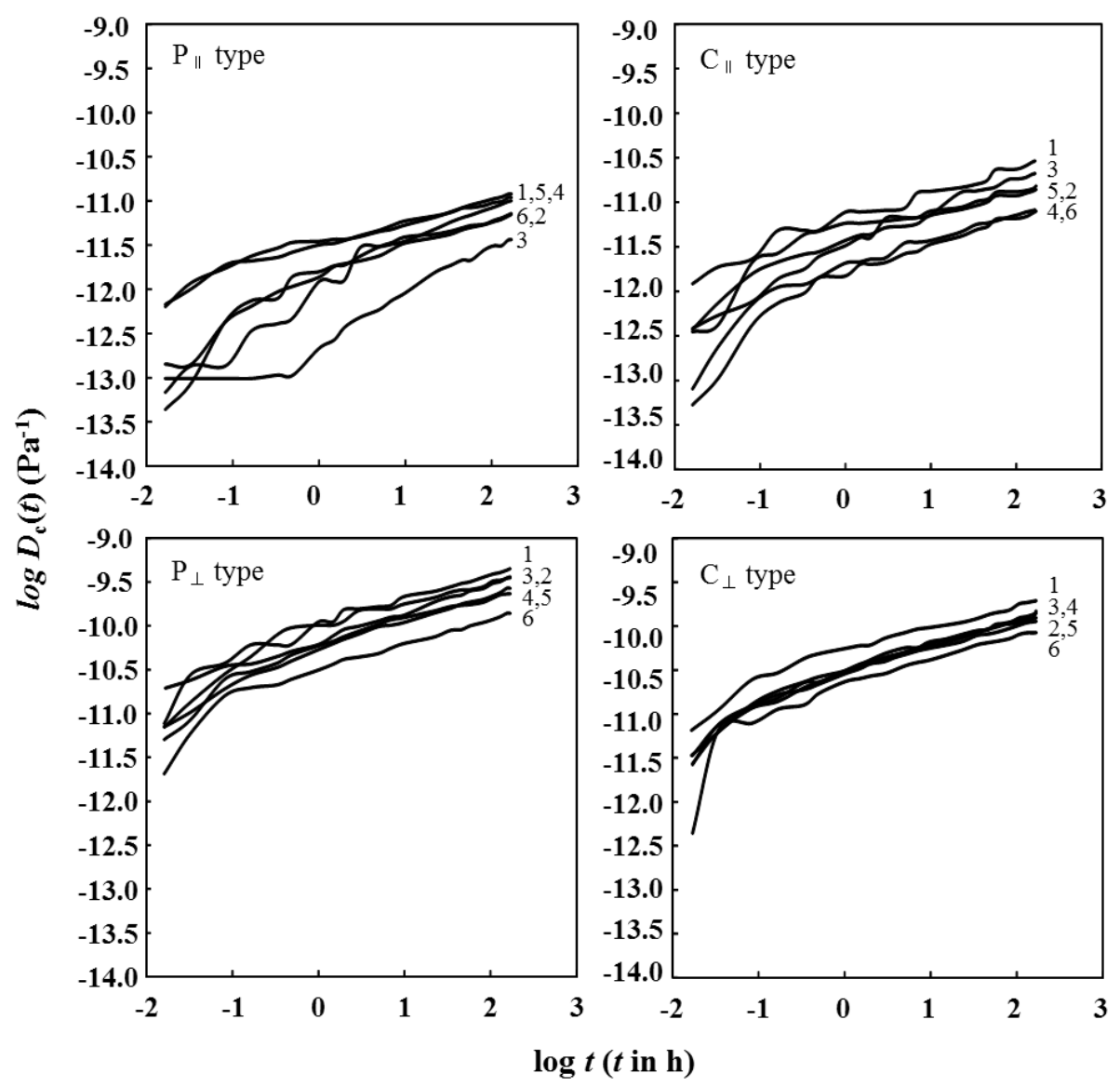

Fig. 4. Double logarithm plots of creep deformation and time for typical examples of $\mathrm{P}_{\|}, \mathrm{P}_{\perp}, \mathrm{C}_{\|}$and $\mathrm{C}_{\perp}$ type laminated woods. 1: Japanese cedar, 2: Japanese cypress, 3: Japanese larch, 4: Chestnut, 5: Tulip tree, 6: Oriental oak.

were little differences between softwoods and hardwoods. The $N$ values of $\mathrm{P}_{\perp}$ type that were composed of perpendicular-direction laminae in all layers were in the range of $0.221-0.284$, and $\mathrm{P}_{\perp}(\mathrm{T})$ composed of tulip tree had the lowest value, while $\mathrm{P}_{\perp}(\mathrm{C})$ composed of chestnut had the highest value. The values were increased with increasing density of the wood species. The values were in order of $\mathrm{P}_{\perp}(\mathrm{C})>$ $\mathrm{P}_{\perp}(\mathrm{H})>\mathrm{P}_{\perp}(\mathrm{O})>\mathrm{P}_{\perp}(\mathrm{S})>\mathrm{P}_{\perp}(\mathrm{L})>\mathrm{P}_{\perp}(\mathrm{T})$. It was found that there were little differences between softwoods and hardwoods. On the other hand, the $N$ values of $\mathrm{C}_{\|}$type cross-laminated woods that were composed of parallel-direction laminae in the faces and perpendicular-direction lamina in the core were in the range of 0.251 0.292 , and $\mathrm{C}_{\|}(\mathrm{T})$ composed of tulip tree had the lowest value, and had the highest value in $\mathrm{C}_{\|}(\mathrm{C})$ composed of chestnut. The values were in order of $\mathrm{C}_{\|}(\mathrm{C})>\mathrm{C}_{\|}(\mathrm{O})>\mathrm{C}_{\|}(\mathrm{H})=\mathrm{C}_{\|}(\mathrm{L})$ 
Bending Creep Property of Cross-Laminated Woods Made With Six Domestic Species

Table 2. Results of bending creep test for each type of parallel- and cross-laminated woods

\begin{tabular}{|c|c|c|c|c|c|c|}
\hline Types & $\begin{array}{l}\text { Density } \\
\left(\mathrm{Mg} / \mathrm{m}^{3}\right)\end{array}$ & $N$ & $\begin{array}{c}A \\
\left(10^{-11} \mathrm{~Pa}^{-1}\right)\end{array}$ & $\begin{array}{c}D(0.008) \\
\left(10^{-11} \mathrm{~Pa}^{-1}\right) \\
\end{array}$ & $\begin{array}{c}D_{\mathrm{c}}(168) \\
\left(10^{-11} \mathrm{~Pa}^{-1}\right)\end{array}$ & $\begin{array}{c}R_{\mathrm{c}} \\
(\%)\end{array}$ \\
\hline $\mathrm{P}_{\|}(\mathrm{S})$ & 0.391 & 0.320 & $0.295(50.6)$ & $16.73(12.2)$ & 1.34 (20.6) & $8.0(18.5)$ \\
\hline $\mathrm{P}_{\|}(\mathrm{H})$ & $0.437(0.8)$ & 0.261 & $0.174(39.2)$ & $10.80(3.9)$ & $0.67(21.2)$ & $6.2(20.2)$ \\
\hline $\mathrm{P}_{\|}(\mathrm{L})$ & $0.589(2.8)$ & $0.493(50.7)$ & $0.141(145.5)$ & $8.41(8.9)$ & 0.73 (61.6) & $8.4(53.2)$ \\
\hline $\mathrm{P}_{\|}(\mathrm{C})$ & $0.562(2.5)$ & $0.322(27.7)$ & $0.230(74.8)$ & 11.44 (8.6) & 1.04 (34.4) & $9.0(30.5)$ \\
\hline $\mathrm{P}_{\|}(\mathrm{T})$ & $0.558(5.6)$ & $0.263(10.1)$ & 0.243 (31.5) & $9.67(15.8)$ & 0.96 (32.9) & $9.8(19.5)$ \\
\hline $\mathrm{P}_{\|}(\mathrm{O})$ & $0.860(2.9)$ & $0.287(4.4)$ & $0.181(26.8)$ & $7.11(8.0)$ & 0.78 & $11.0(14.7)$ \\
\hline $\mathrm{P}_{\perp}(\mathrm{S})$ & $0.398(2.6)$ & $0.241(11.7)$ & $11.38(30.7)$ & $122.7(8.8)$ & $41.26(23.4)$ & $33.4(17.1)$ \\
\hline $\mathrm{P}_{\perp}(\mathrm{H})$ & $0.463(2.9)$ & $0.280(12.0)$ & 8.07 (14.8) & $109.3(4.8)$ & 34.04 (5.6) & $31.1(3.5)$ \\
\hline $\mathrm{P}_{\perp}(\mathrm{L})$ & $0.566(7.3)$ & 0.239 & $10.11(2.6)$ & $87.32(7.6)$ & 35.76 (4.9) & 41.2 (11.4) \\
\hline $\mathrm{P}_{\perp}(\mathrm{C})$ & 0.575 & $0.284(11.2)$ & 6.07 (21.4) & 72.35 (10.6) & $26.04(8.1)$ & $36.1(7.6)$ \\
\hline $\mathrm{P}_{\perp}(\mathrm{T})$ & $0.609(8.4)$ & $0.221(26.0)$ & $7.32(10.0)$ & $75.43(7.3)$ & $22.40(30.0)$ & $30.0(32.8)$ \\
\hline $\mathrm{P}_{\perp}(\mathrm{O})$ & $0.861(2.9)$ & $0.277(2.9)$ & $3.22(6.6)$ & $37.09(3.1)$ & $13.45(8.1)$ & $36.2(5.3)$ \\
\hline $\mathrm{C}_{\|}(\mathrm{S})$ & $0.383(2.8)$ & $0.252(9.4)$ & $0.761(19.0)$ & $19.75(24.9)$ & $2.82(13.5)$ & $15.2(38.9)$ \\
\hline $\mathrm{C}_{\|}(\mathrm{H})$ & $0.467(4.9)$ & $0.254(7.5)$ & $0.394(6.5)$ & $13.41(7.7)$ & $1.42(12.1)$ & $10.6(4.3)$ \\
\hline $\mathrm{C}_{\|}(\mathrm{L})$ & $0.574(2.1)$ & $0.254(10.8)$ & 0.496 (26.4) & 10.84 (11.4) & 1.88) (28.2) & $17.2(20.6)$ \\
\hline $\mathrm{C}_{\|}(\mathrm{C})$ & $0.563(2.1)$ & $0.292(2.9)$ & 0.266 (34.9) & 12.75 (16.8) & 1.18 (37.1) & $9.1(19.9)$ \\
\hline $\mathrm{C}_{\|}(\mathrm{T})$ & $0.579(5.4)$ & 0.251 & $0.362(21.1)$ & 10.35 (18.4) & 1.33 (37.9) & $12.5(22.7)$ \\
\hline $\mathrm{C}_{\|}(\mathrm{O})$ & $0.845(2.3)$ & $0.274(13.0)$ & $0.211(23.3)$ & 7.17 (3.6) & $0.85(18.1)$ & $11.9(16.8)$ \\
\hline $\mathrm{C}_{\perp}(\mathrm{S})$ & $0.405(2.4)$ & $0.241(1.9)$ & $5.59(10.4)$ & $86.62(8.3)$ & $19.80(12.7)$ & $22.8(6.6)$ \\
\hline $\mathrm{C}_{\perp}(\mathrm{H})$ & $0.459(4.0)$ & $0.260(6.6)$ & 3.54 (3.9) & $75.40(7.8)$ & 13.43 (11.8) & $17.8(6.7)$ \\
\hline $\mathrm{C}_{\perp}(\mathrm{L})$ & $0.583(5.7)$ & $0.252(8.0)$ & $3.85(26.4)$ & $61.00(10.9)$ & 14.47 (18.8) & 23.7 (12.6) \\
\hline $\mathrm{C}_{\perp}(\mathrm{C})$ & $0.569(1.4)$ & $0.277(10.0)$ & $3.35(10.1)$ & $63.09(3.7)$ & 13.84 (4.9) & $22.0(6.9)$ \\
\hline $\mathrm{C}_{\perp}(\mathrm{T})$ & $0.585(6.2)$ & $0.234(10.2)$ & $4.15(20.4)$ & $58.31(10.0)$ & 13.23 (20.4) & $22.8(20.4)$ \\
\hline $\mathrm{C}_{\perp}(\mathrm{O})$ & $0.851(4.2)$ & 0.270 & $2.21(4.3)$ & $32.36(7.0)$ & $8.58(7.1)$ & $26.5(4.4)$ \\
\hline
\end{tabular}

$N$ and $A$ are the constant values in the exponential regression between creep compliance and time $\left[D_{\mathrm{c}}(t)=A t^{\mathrm{N}}\right], D(0.008)$ is initial compliance (at $0.008 \mathrm{~h}), D_{\mathrm{c}}(168)$ is creep compliance except for initial compliance at $168 \mathrm{~h}(D(168)-D(0.008))$, $R_{\mathrm{c}}$ is relative creep $\left(100\left(D_{\mathrm{c}}(168) /\right.\right.$ $D(0.008)$ ). Each value in parentheses is the coefficient of variation (\%).

$>\mathrm{C}_{\|}(\mathrm{S})>\mathrm{C}_{\|}(\mathrm{T})$. The cross-laminated woods made with softwoods were lower than those made with hardwoods except for that made with tulip tree. However, it was found that there were little differences by the density of species. The $N$ values of $\mathrm{C}_{\perp}$ type cross-laminated woods that were composed of perpendicular-direction laminae in the faces and paral- lel-direction lamina in the core were in the range of $0.234-0.277$, and $C_{\perp}(T)$ composed of tulip tree had the lowest value like $\mathrm{C}_{\|}$type, and had the highest value in $\mathrm{C}_{\perp}(\mathrm{C})$ composed of chestnut. The values were in order of $\mathrm{C}_{\perp}(\mathrm{C})$ $>\mathrm{C}_{\perp}(\mathrm{O})>\mathrm{C}_{\perp}(\mathrm{H})>\mathrm{C}_{\perp}(\mathrm{L})>\mathrm{P}_{\perp}(\mathrm{S})>\mathrm{P}_{\perp}(\mathrm{T})$. On the whole, the values were lower in those made with softwoods than in those made with 

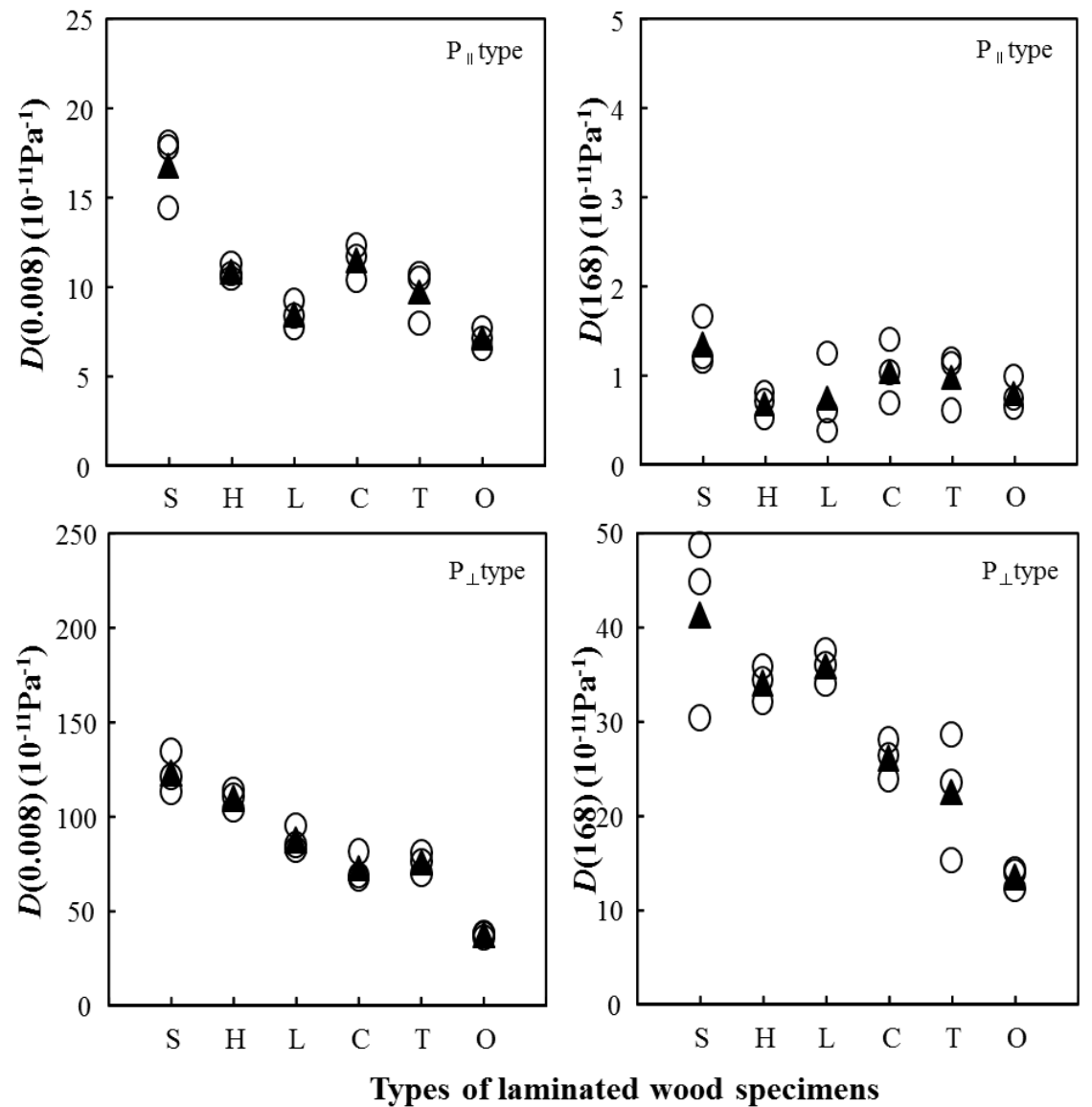

Fig. 5. Initial and creep compliances of parallel-laminated woods. $D(0.008)$ is initial compliance (at $0.008 \mathrm{~h}$ ); $D_{\mathrm{c}}(168)$ is creep compliance except for initial compliance at $168 \mathrm{~h}(D(168)-D(0.008)) ; \mathrm{S}, \mathrm{H}, \mathrm{L}, \mathrm{C}, \mathrm{T}$ and $\mathrm{O}$ are the same as in Fig. 3.

hardwoods. The difference by density was not clear. These values were in a similar range as those of the cross-laminated woods that were made with Japanese cedar (Park et al., 2002; 2006) except for Japanese larch with high coefficient of variation. And these value were slightly lower than that of glulam under constant humidity condition and were considerably lower than that under humidity change. Also, these values were in a similar range as those of wood-based boards such as plywood, particle board and wood-wood based board laminated materials (Nakai, 1878; Arima, 1981; Park et al., 2010). The $A$ values of parallel- and cross-laminated woods proportionally increased with increasing creep compliances. The values were higher in the laminated woods made with softwoods than in those made with hardwoods on the whole. 


\subsection{Initial and creep deformation of parallel- and cross-laminated woods}

The results of creep test of parallel- and cross-laminated woods are shown in Table 2 and Initial and creep compliances of parallel-laminated woods are shown in Fig. 5.

For the initial deformation of $\mathrm{P}_{\|}$type, $\mathrm{P}_{\|}(\mathrm{S})$ composed of Japanese cedar with the lowest density of the tested specimens had the greatest compliance, and had the lowest value in $\mathrm{P}_{\|}(\mathrm{O})$ composed of oriental oak with the highest density of the tested specimens. The initial compliances were in order of $\mathrm{P}_{\|}(\mathrm{S})>\mathrm{P}_{\|}(\mathrm{C})$ $>\mathrm{P}_{\|}(\mathrm{H})>\mathrm{P}_{\|}(\mathrm{T})>\mathrm{P}_{\|}(\mathrm{L})>\mathrm{P}_{\|}(\mathrm{O})$. For the creep deformation of $\mathrm{P}_{\|}$type, $\mathrm{P}_{\|}(\mathrm{S})$ composed of Japanese cedar had the greatest compliance, and had the lowest value in $\mathrm{P}_{\|}(\mathrm{H})$ composed of Japanese cypress. The creep compliances were in order of $\mathrm{P}_{\|}(\mathrm{S})>\mathrm{P}_{\|}(\mathrm{C})>\mathrm{P}_{\|}(\mathrm{T})>$ $\mathrm{P}_{\|}(\mathrm{O})>\mathrm{P}_{\|}(\mathrm{L})>\mathrm{P}_{\|}(\mathrm{H})$. For the initial deformation of $\mathrm{P}_{\perp}$ type, $\mathrm{P}_{\perp}(\mathrm{S})$ composed of Japanese cedar had the greatest value, and had the lowest value in $\mathrm{P}_{\perp}(\mathrm{O})$ composed of oriental oak. The initial compliances were in order of $\mathrm{P}_{\perp}(\mathrm{S})>\mathrm{P}_{\perp}(\mathrm{H})>\mathrm{P}_{\perp}(\mathrm{L})>\mathrm{P}_{\perp}(\mathrm{T})>\mathrm{P}_{\perp}(\mathrm{C})>$ $\mathrm{P}_{\perp}(\mathrm{O})$. For the creep deformation of $\mathrm{P}_{\perp}$ type, $\mathrm{P}_{\perp}(\mathrm{S})$ composed of Japanese cedar had the greatest value, and had the lowest value in $\mathrm{P}_{\perp}(\mathrm{O})$ composed of oriental oak. The creep compliances were in order of $\mathrm{P}_{\perp}(\mathrm{S})>\mathrm{P}_{\perp}(\mathrm{L})>$ $\mathrm{P}_{\perp}(\mathrm{H})>\mathrm{P}_{\perp}(\mathrm{C})>\mathrm{P}_{\perp}(\mathrm{T})>\mathrm{P}_{\perp}(\mathrm{O})$. It was found that cross-laminated woods made with softwoods were higher than those made with hardwoods on the whole, and their values showed the density dependence. The initial compliances of $\mathrm{P}_{\perp}$ type were 5.2-10.4 times higher than those of $\mathrm{P}_{\|}$type, and the creep compliances of $\mathrm{P}_{\perp}$ type were $17.1-50.5$ times higher than those of $\mathrm{P}_{\|}$type. From these results, the creep deformation between both parallel-laminated woods was found to be considerably greater than the initial deformation. The deference was relatively great in those made with Japanese cypress and Japanese larch and was small in that made with oriental oak.

As shown in Fig. 6, for the initial deformation of $\mathrm{C}_{\|}$type that was composed of parallel-direction laminae in the faces and perpendicular-direction lamina in the core, $\mathrm{C}_{\|}(\mathrm{S})$ composed of Japanese cedar showed the highest initial compliance, and showed the lowest initial compliance in $\mathrm{C}_{\|}(\mathrm{O})$ composed of oriental oak. The values were in order of $\mathrm{C}_{\|}(\mathrm{S})>\mathrm{C}_{\|}(\mathrm{H})>$ $\mathrm{C}_{\|}(\mathrm{C})>\mathrm{C}_{\|}(\mathrm{L})>\mathrm{C}_{\|}(\mathrm{T})>\mathrm{C}_{\|}(\mathrm{O})$. The creep compliances of $\mathrm{C}_{\|}$type showed the highest values in $\mathrm{C}_{\|}(\mathrm{S})$ composed of Japanese cedar and showed the lowest value in in $\mathrm{C}_{\|}(\mathrm{O})$ composed of oriental oak like the initial deformation. The values were in order of $\mathrm{C}_{\|}(\mathrm{S})$ $>\mathrm{C}_{\|}(\mathrm{L})>\mathrm{C}_{\|}(\mathrm{H})>\mathrm{C}_{\|}(\mathrm{T})>\mathrm{C}_{\|}(\mathrm{C})>\mathrm{C}_{\|}(\mathrm{O})$. The initial compliance showed $1.0-1.3$ times higher than that of $\mathrm{P}_{\|}$type, and the creep compliance showed 1.1 - 2.6 times higher than that of $\mathrm{P}_{\|}$type, both the initial and creep compliances were increased by cross-laminating, and the extent of the increase was found to be higher in creep deformation than in initial deformation. As shown in Fig. 5, the initial deformation of $\mathrm{C}_{\perp}$ type that were composed of 

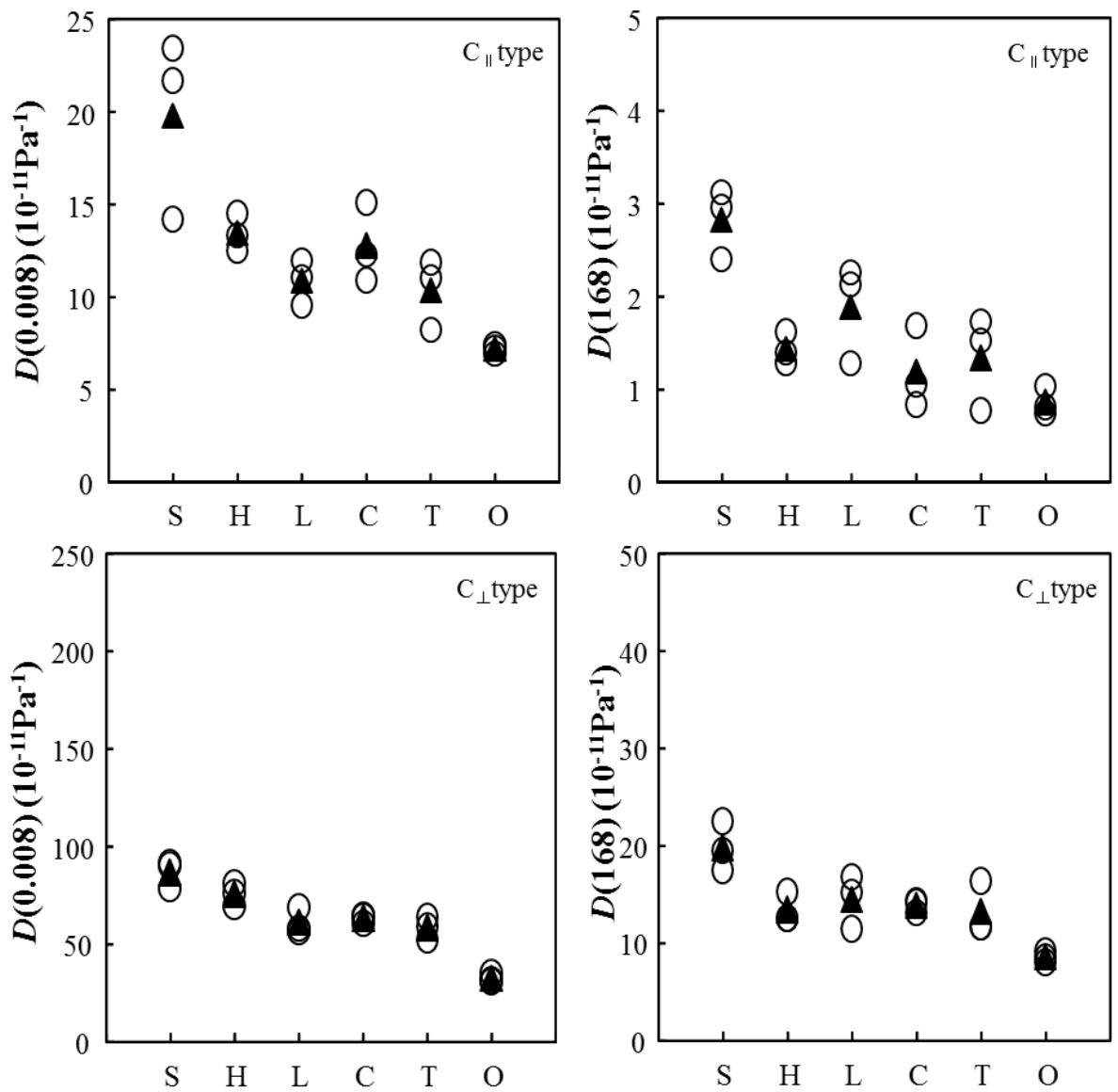

Fig. 6. Initial and creep compliances of cross-laminated woods. $D(0.008)$ is initial compliance (at $0.008 \mathrm{~h})$; $D_{\mathrm{c}}(168)$ is creep compliance except for initial compliance at $168 \mathrm{~h}(D(168)-D(0.008))$; S, H, L, C, T and O are the same as in Fig. 3.

perpendicular-direction laminae in the faces and parallel-direction lamina in the core showed the highest values in $\mathrm{C}_{\perp}(\mathrm{S})$ composed of Japanese cedar, and had the lowest value in $\mathrm{C}_{\perp}(\mathrm{O})$ composed of oriental oak. The values were in order of $\mathrm{C}_{\perp}(\mathrm{S})>\mathrm{C}_{\perp}(\mathrm{H})>\mathrm{C}_{\perp}(\mathrm{C})>\mathrm{C}_{\perp}(\mathrm{L})>\mathrm{C}_{\perp}(\mathrm{T})$ $>\mathrm{C}_{\perp}(\mathrm{O})$, and showed the density dependence on the whole. The creep deformation of $\mathrm{C}_{\perp}$ type showed the highest values in $\mathrm{C}_{\perp}(\mathrm{S})$ composed of Japanese cedar, and had the lowest value in $\mathrm{C}_{\perp}(\mathrm{O})$ composed of oriental oak. The values were in order of $\mathrm{C}_{\perp}(\mathrm{S})>\mathrm{C}_{\perp}$ (L) $>\mathrm{C}_{\perp}(\mathrm{C})>\mathrm{C}_{\perp}(\mathrm{H})>\mathrm{C}_{\perp}(\mathrm{T})>\mathrm{C}_{\perp}(\mathrm{O})$. The initial compliance showed $0.69-0.87$ times lower than that of $\mathrm{P}_{\perp}$ type, and the creep compliance showed $0.39-0.64$ times lower than that of $\mathrm{P}_{\perp}$ type, both the initial and creep deformation was considerably decreased by cross-laminating, and the extent of the decrease was found to be markedly higher in creep 

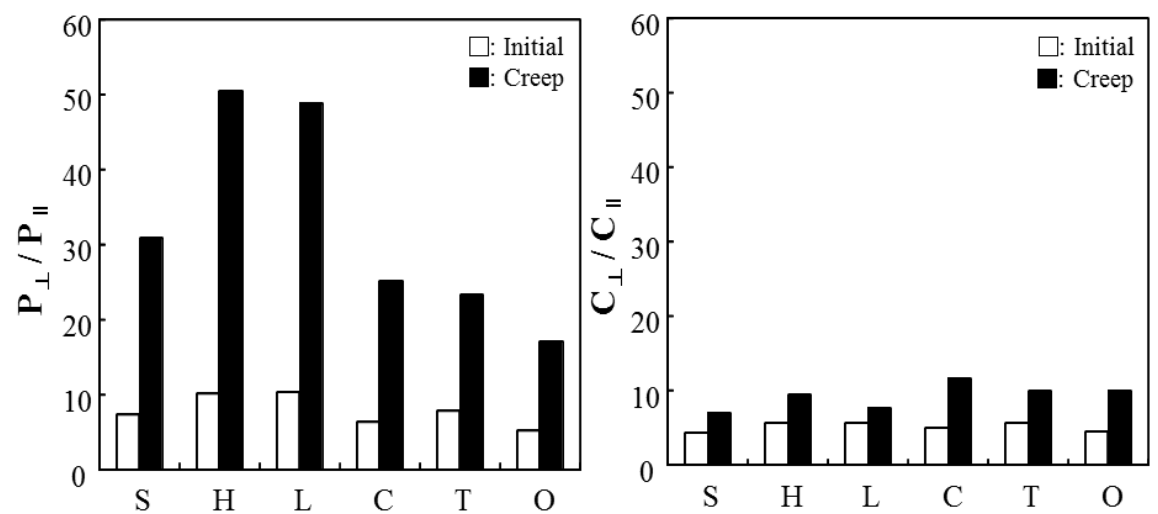

Types of laminated wood specimens

Fig. 7. Anisotropy of initial and creep compliances for parallel- and cross-laminated woods. $\mathrm{P}_{\perp} / \mathrm{P}_{\|}$is the ratio of initial compliance or creep compliance of $\mathrm{P}_{\perp}$ type to $\mathrm{P}_{\|}$type; $\mathrm{C}_{\perp} / \mathrm{C}_{\|}$is the ratio of initial compliance or creep compliance of $\mathrm{C}_{\perp}$ type to $\mathrm{C}_{\|}$type; $\mathrm{S}, \mathrm{H}, \mathrm{L}, \mathrm{C}, \mathrm{T}$ and $\mathrm{O}$ are the same as in Fig. 3.

deformation than in initial deformation.

Fig. 7 shows the creep anisotropies for parallel- and cross-laminated woods. The anisotropies for the initial compliances of the cross-laminated woods were decreased to 0.54 0.86 times those of parallel-laminated woods by cross-laminating, and those of creep compliance were decreased to $0.28-0.67$ times those of parallel-laminated woods by cross-laminating. The extent of the decrease was found to be much greater in creep deformation than in initial deformation.

\subsection{Relative creep of parallel- and cross-laminated woods}

The relative creep expressed as the percentage of creep compliance to initial compliance is shown in Fig. 8. The relative creep for $\mathrm{P}_{\|}$type showed $6.2 \%\left(\mathrm{P}_{\|}(\mathrm{H})\right)-11.0 \% \quad\left(\mathrm{P}_{\|}(\mathrm{O})\right)$. The values were in order of $\mathrm{P}_{\|}(\mathrm{O})>\mathrm{P}_{\|}(\mathrm{T})>$ $\mathrm{P}_{\|}(\mathrm{C})>\mathrm{P}_{\|}(\mathrm{L})>\mathrm{P}_{\|}(\mathrm{S})>\mathrm{P}_{\|}(\mathrm{H})$. The relative creep for $\mathrm{P}_{\perp}$ type showed $30.0 \%\left(\mathrm{P}_{\|}(\mathrm{T})\right)$ $41.2 \%\left(\mathrm{P}_{\|}(\mathrm{L})\right)$. The values were in order of $\mathrm{P}_{\perp}(\mathrm{L})>\mathrm{P}_{\perp}(\mathrm{O})>\mathrm{P}_{\perp}(\mathrm{C})>\mathrm{P}_{\perp}(\mathrm{S})>\mathrm{P}_{\perp}(\mathrm{H})>$ $\mathrm{P}_{\perp}(\mathrm{T})$. These values showed 2.4 - 5.0 times higher than those of $\mathrm{P}_{\|}$type. On the other hand, the relative creep of $\mathrm{C}_{\|}$type were in the range of $9.1 \%\left(\mathrm{C}_{\|}(\mathrm{C})\right)-17.2 \%\left(\mathrm{C}_{\|}(\mathrm{L})\right)$. The values were in order of $\mathrm{C}_{\|}(\mathrm{L})>\mathrm{C}_{\|}(\mathrm{S})>$ $\mathrm{C}_{\|}(\mathrm{T})>\mathrm{C}_{\|}(\mathrm{O})>\mathrm{C}_{\|}(\mathrm{H})>\mathrm{C}_{\|}(\mathrm{C})$, and the values were 1.5 - 1.6 times higher than those of $\mathrm{P}_{\|}$type. The relative creep of $\mathrm{C}_{\perp}$ type were in the range of $17.8 \%\left(\mathrm{C}_{\perp}(\mathrm{H})\right)-26.5 \%$ $\left(\mathrm{C}_{\perp}(\mathrm{O})\right)$. The values were in order of $\mathrm{C}_{\perp}(\mathrm{O})>$ $\mathrm{C}_{\perp}(\mathrm{L})>\mathrm{C}_{\perp}(\mathrm{S})=\mathrm{C}_{\perp}(\mathrm{T})>\mathrm{C}_{\perp}(\mathrm{C})>\mathrm{C}_{\perp}(\mathrm{H})$. These values showed $0.59-0.64$ times lower than those of $\mathrm{P}_{\perp}$ type and $1.4-2.2$ times higher than those of $\mathrm{C}_{\|}$type.

\section{CONCLUSIONS}

Cross-laminated woods were made with six domestic species, and bending creep behaviors 


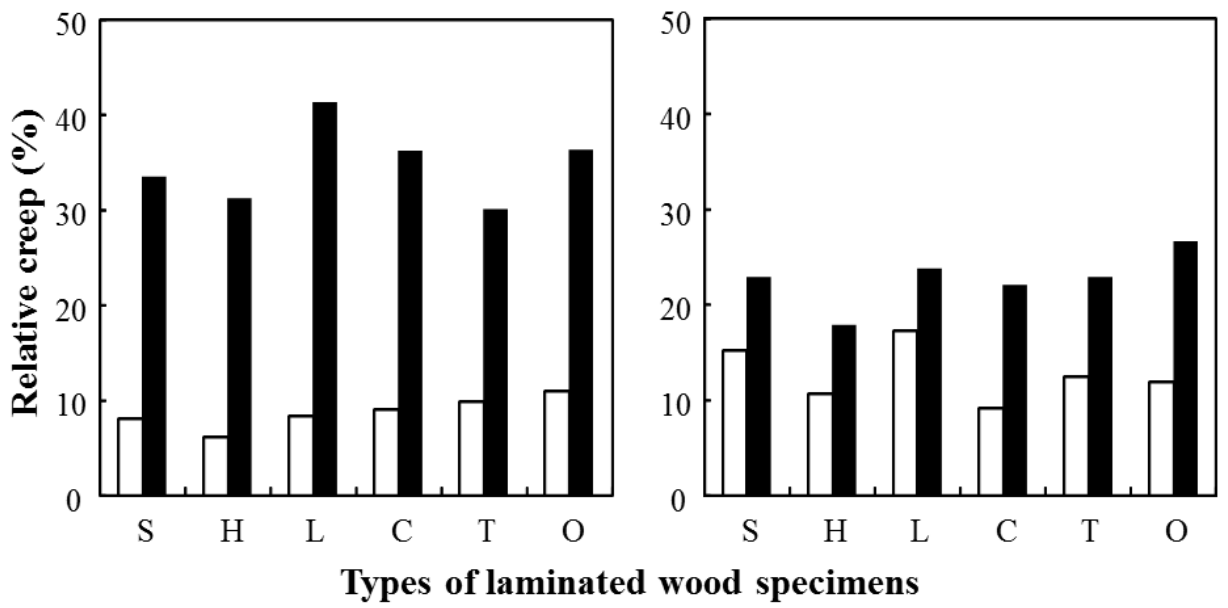

Fig. 8. Comparison of relative creep (the percentage of creep compliance to initial compliance) for parallel- and cross-laminated woods. S, H, L, C, T and $\mathrm{O}$ are the same as in Fig. 3.

were investigated. The conclusions obtained were as follows:

1) The creep curves showed the shape of exponential function plot which was sharply increased at upper right side, and the extent of the increase was higher in softwoods with low densities than in hardwoods with high densities. The creep curves showed a curvilinear behavior for about 30 minute to 1 hour after loading, but then showed a linear behavior. Therefore, it was found that the creep curves after 1 hour were able to estimate by fitting it to the power law.

2) The initial and creep compliances for cross-laminated woods were greatest in that made with Japanese cedar having a low density, and were lowest in that made with oriental oak having a high density.

3) By cross-laminating, initial and creep compliances of parallel-laminated woods $\left(\mathrm{P}_{\perp}\right.$ type) composed of perpendicular-direction laminae in all layers considerably decreased, and the extent of the decrease was greater in creep deformation than in initial deformation.

4) The creep anisotropies expressed as ratios of creep compliance perpendicular to the grain of face laminae versus that parallel to the grain of face laminae of laminated woods were 1: $0.54-0.86$ for initial deformation, and 1: $0.28-0.67$ for creep deformation. By cross-laminating, the values were markedly decreased, and the extent of the decrease was found to be greater in creep deformation than in initial deformation.

\section{REFERENCES}

Aratake, S., Morita, H., Arima, T. 2002. Creep of various structural members in ambient conditions I . Estimation of future deflections considering 
the longevity of wooden structures (in Japanese). Mokuzai Gakkaishi 48: 233 240.

Arima, T., Sato, M., Mashita, K. 1981. Studies on evaluation method for long-term performance of wood-based materials and elements (in Japanese). Report of the Building Research Institute No.95: 25 80.

Bryan, E.L., Schniewind, A.P. 1965. Strength and rheological properties of particleboard. Forest Products Journal 15: $143 \sim 148$.

Fushitani, M., Bono, Y. 1975. Bending creep of laminated woods (in Japanese). Wood Industry, Japan 30(5): $22 \sim 24$.

Gülzow, A., Richter, K., Stelger, R. 2011. Influence of wood moisture content on bending and shear stiffness of cross-laminated timber panels. European Journal of Wood and Wood Products 69: $193 \sim 197$.

Goto, T., Fukushima, A., Nakayama, S., Furono, T. 2014. Bending properties of missed-species, three-ply CLTs (Cross-Laminated Timbers) with inner layer of sugi. Mokuzai Gakkaishi 60: 336 345. In Japanese with summary in English.

Gavric, I., Fragiacomo, M., Ceccotti, A. 2015a. Cyclic behavior of typical metal connectors for cross-laminated (CLT) structures. Materials and Structures 48: $1841 \sim 1857$.

Gavric, I., Fragiacomo, M., Ceccotti, A. 2015 b. Cyclic behavior of typical screwed connections for cross-laminated (CLT) structures. European Journal of Wood and Wood Products 73: 179 191.

Hoyle, R.J., Itani, R.Y., Anderson, J.T. 1994. The effect of moisture cycling on creep of small glued laminated beams. Wood and Fiber Science 26: $556 \sim 562$.

Ido, H., Nagao, H., Miura, S., Miyatake, A. 2014. Compressive strength properties perpendicular to the grain of cross-laminated timber (CLT) com- posed of sugi laminations. Mokuzai Gakkaishi 60: 16 22. In Japanese with summary in English.

Korea Forest Service. 2016. 2016 Annual report on forests and forestry. pp. $3 \sim 4$.

Moriizumi, S. 1981. Creep properties of wood-based boards under plate shear test (in Japanese). Journal of the Hokkaido Forest Products Research Institute No.359: 6〜14.

Moslemi, A.A. 1964. Some aspects of viscoelastic behavior of hardboard. Forest Products Journal 14: $337 \sim 342$.

Nakashima, S., Kitamori, A., Komatsu, K. 2014. Embedment and shear strengths of cross laminated timber and their dependence on angular orientation. Mokuzai Gakkaishi 60: 216 226. In Japanese with summary in English.

Nakai, T. 1978. Bending creep test on wood-based boards I (in Japanese). Wood Industry, Japan 33: $158 \sim 160$.

Okabe, M., Yasumura, M., Kobayashi, K., Fujita, K. 2014. Prediction of bending stiffness and moment carrying capacity of sugi cross-laminated timber. Journal of Wood Science 60: 49 58.

Okuma, M., Tashiro, H. 1968. Effect of adhesive on creep of plywood (in Japanese). Wood Industry, Japan 23: $168 \sim 170$.

Park, H.M., Fushitani, M. 2014. Calculations of shear moduli of three-ply cross-laminated wood panels from shear moduli of individual laminae. Wood and Fiber Science 46: 195 205.

Park, H.M., Fushitani, M. 2006. Effects of component ratio of the face and core laminae on static bending strength performances of three-ply cross-laminated wood panels made with sugi (Cryptomeria japonica). Wood and Fiber Science 38: $278 \sim 291$.

Park, H.M., Fushitani, M., Byeon, H.S. 2009. Derivation of an equation for calculating shear 
modulus of three-ply laminated material beam from shear moduli of individual laminae and its application. Journal of Wood Science 55: 181 189.

Park, H.M., Fushitani M., Byeon H.S., Yang J.K. 2016. Static bending strength performances of cross-laminated wood panels made with six species. Wood and Fiber Science 48: 68 80 .

Park, H.M., Fushitani M., Kubo T., Sato K., Byeon H.S. 2002. Bending creep performance of cross-laminated sugi wood. Mokuzai Gakkaishi 48: 166 177. In Japanese with summary in English.

Park, H.M., Fushitani M., Ohtsuka T., Nakajima T., Sato K., Byeon H.S. 2001. Effect of annual ring angle on static bending strength performances of cross-laminated woods made with sugi wood. Mokuzai Gakkaishi 47: 22 32. In Japanese with summary in English.

Park, H.M., Fushitani M., Sato K., Kubo T., Byeon H.S. 2006. Bending creep performances of three-ply cross-laminated woods made with five species. Journal of Wood Science 52: 220 229 .

Park, H.M., Fushitani M., Sato K., Kubo T., Byeon H.S. 2003. Static bending strength performances of cross-laminated woods made with five species. Journal of Wood Science 49: 411 417.

Park, H.M., Kang D.H., Choi Y.E., Ahn S.Y., Ryu H.S., Byeon H.S. 2010. Bending creep performances of hybrid laminated woods composed of wood-wood based boards. Journal of the Korean Wood Science and Technology 38: 1 10.

Saito, F., Ikeda M., Ogawa K. 1980. Time-related flexural behavior of particleboards under long term load (in Japanese). Mokuzai Gakkaishi 26: $714 \sim 718$.

Schniewind, A.P. 1968. Recent progress in the study of the rheology of wood. Wood Science and Technology 2: 188 206.

Sebera, V., Muszyński L, Tippner J, Noyel M, Pisaneschi T, sundberg B. 2015. FE analysis panel subjected to torsion and verified by DIC. Materials and Structures 48: 451 459.

Stelger, R., Gülzow A., Czaderski C., Howald M., Niemz P. 2012. Comparison of bending stiffness of cross-laminated solid timber derived by modal analysis of full panels and by bending tests of strip-shaped specimens. European Journal of Wood and Wood Products 70: 141 153. 